\title{
The Effect of Entrepreneurial Marketing on the Performance of Small and Medium-sized Enterprises
}

\author{
Gemechu Abdissa Shuremo ${ }^{1, *}$, Csaba Bálint Illés ${ }^{1}$, Anna Törőné Dunay ${ }^{1}$ \\ ${ }^{1}$ Faculty of Economics and Social Sciences, Szent István University 1 Páter K. Str., Gödöllő, 2100, Hungar
}

\begin{abstract}
Entrepreneurial marketing is a non-conventional marketing technique that provides business owners a method to successfully operate their business with limited resources. The main objective of this study is to therefore investigate whether entrepreneurial marketing can affect the performance of small and medium-sized enterprises operating in Ethiopia, specifically in the city of Jimma. A purposive sampling technique was employed to gather data from 100 business owners that have been on market for more than 7 years. The data were analysed using Minitab and SPSS statistical software packages. The study showed that some elements of entrepreneurial marketing indeed affect the performance of small and medium-sized enterprises. Innovation orientation and customer intensity have a positive relationship with the performance of small and medium-sized enterprises and are statistically significant, while risk-taking orientation has a negative relationship and is statistically significant. It is therefore recommended that business owners apply the concept of entrepreneurial marketing to leverage their limited resources to cope with competitors and maintain the sustainability of their business.
\end{abstract}

Keywords: entrepreneurial marketing; sustainability; performance; small and medium-sized enterprises

\section{Introduction}

The concept of marketing indicates how to recognize consumer wants and to match the marketing activities with other functional areas of a company in order to achieve an organizational objective through the fulfilment of customer needs. The concept of marketing is a widely studied field. However, since studies have been mainly focused on large industries, it is difficult to apply their findings directly to small and medium-sized enterprises. According to Chitrakar [1], the marketing activities employed by small and medium-sized enterprises are different from the conventional concept of marketing.

Researchers have suggested a new concept of marketing which best matches the characteristics of small and medium-sized enterprises. According to Stokes [2], entrepreneurial marketing is a holistic concept that best fits the marketing approaches of small and medium-sized enterprises. According to Becherer et al. [3], entrepreneurial marketing is a blend of entrepreneurship and marketing. Fink et al.[4], state that entrepreneurial marketing contemplates market orientation and entrepreneurial behaviours; it is an amalgamation of entrepreneurship and marketing disciplines.

Entrepreneurial marketing is a scientific concept that observes an entrepreneur ability in identifying business problems and exploiting current opportunities [5]. According to Morris et al. [6], entrepreneurial marketing is an opportunity driven and opportunity seeking way of thinking and acting. The author indicates that entrepreneurial marketing is a marketing discipline linked to entrepreneurial creative thinking and the utilization of an opportunity through innovative marketing activities. Entrepreneurial marketing is focused on creating a value proposition for current and potential customers and other stakeholders [7].

This study addresses the question of whether entrepreneurial marketing affects the performance of small and medium-sized enterprises operating in Ethiopia. Poor management, resource constraint, insufficient profit, low demand for products and services are some of the problems that small and medium-sized enterprises are facing today. Even though this study argues that entrepreneurial marketing has an impact on both large and small companies, the concept is more applicable to the problems of small and medium-sized enterprises with regards to

${ }^{*}$ Corresponding author: gemechu.mtu@gmail.com 
determining their sustainability. Because entrepreneurial marketing focuses on new approaches to business solutions, resource leverage, risk management and value creation, it is very much dependent on the company's circumstances [8].

The subsequent parts of this contribution are structured as follows: overview of the concept of entrepreneurial marketing; extensive literature review of the variables used in this study; outline of the methodology and data used; results and discussion; conclusions and implications for further research.

\section{Literature review}

Entrepreneurship and marketing are traditionally considered as two different academic disciplines. Nowadays, entrepreneurial marketing is a separate discipline an entrepreneur can practice as a best business solution for small companies. Entrepreneurial marketing has been recognized and accepted not only by marketing and entrepreneurship disciplines, but also by companies looking for a competitive advantage (Schulte \& Eggers, 2010). An entrepreneur can employ marketing activities in different forms, which is not the same as with conventional marketing theory [9].

According to Morrish et al. [10], entrepreneurial marketing is the process of regular assessment of the environment to find or establish new opportunities and exploiting the occasion effectively to renew competitive advantage. Organizations that implement entrepreneurial marketing are pre-emptive and creative in taking the lead or attracting customers rather than responding to customer needs [11]. Subsequently, entrepreneurial marketing enables companies to focus more attention on new market areas rather than providing services to current ones.

Some studies of entrepreneurial marketing claim that the lack of a conventional marketing strategy in small and medium-sized enterprises is considered an absence of marketing practice as a whole in such companies [12]. There is a basic difference between the traditional concept of marketing practiced by large companies and the new marketing structure of small and medium-sized enterprise [9]. As mentioned in the studies of Schindehutte et al. [11], the entrepreneurial marketing structure consists of seven elements. An overview of the seven elements is presented below.

Table 1. Entrepreneurial marketing and the tasks of entrepreneurship

\begin{tabular}{|c|c|c|c|}
\hline $\begin{array}{l}\text { Elements of } \\
\text { entrepreneurial } \\
\text { marketing }\end{array}$ & $\begin{array}{l}\text { Entrepreneurial } \\
\text { marketing as opportunity } \\
\text { creation and discovery }\end{array}$ & $\begin{array}{l}\text { Entrepreneurial marketing as } \\
\text { opportunity assessment }\end{array}$ & $\begin{array}{l}\text { Entrepreneurial marketing as } \\
\text { opportunity exploitation }\end{array}$ \\
\hline $\begin{array}{l}\text { Customer } \\
\text { intensity }\end{array}$ & $\begin{array}{l}\text { Customer intensity helps } \\
\text { create cognitive models that } \\
\text { seek out opportunities that } \\
\text { satisfy customers in unique } \\
\text { ways }\end{array}$ & $\begin{array}{l}\text { Customer intensity forces } \\
\text { "customer value propositions" } \\
\text { evaluations to be paramount in } \\
\text { entrepreneurial opportunity } \\
\text { assessment }\end{array}$ & $\begin{array}{l}\text { Customer intensity enhances the } \\
\text { ability of a company to exploit } \\
\text { entrepreneurial opportunities by } \\
\text { focusing on how value can be } \\
\text { created for the customer that results } \\
\text { in long-term profits for the firm }\end{array}$ \\
\hline Value creation & $\begin{array}{l}\text { An emphasis on the } \\
\text { creation of a superior value } \\
\text { proposition will impact the } \\
\text { types of opportunities that } \\
\text { it creates or discovers }\end{array}$ & $\begin{array}{l}\text { An organizational focus on } \\
\text { value creation will force } \\
\text { opportunity assessment to } \\
\text { consider the customer needs }\end{array}$ & $\begin{array}{l}\text { As an organizational focus on value } \\
\text { creation will impact how } \\
\text { entrepreneurial opportunities are } \\
\text { exploited }\end{array}$ \\
\hline $\begin{array}{l}\text { Resource } \\
\text { leveraging }\end{array}$ & $\begin{array}{l}\text { Dickson \& Giglierano [13] } \\
\text { notion of an entrepreneurial } \\
\text { company attempting to } \\
\text { minimize the commitment } \\
\text { of its own organization's } \\
\text { resources, while leveraging } \\
\text { the use of external } \\
\text { resources, specifically when } \\
\text { resources devoted to R\&D } \\
\text { and other knowledge } \\
\text { creation activities may } \\
\text { diminish the company's } \\
\text { ability to create or discover } \\
\text { additional entrepreneurial } \\
\text { opportunities }\end{array}$ & $\begin{array}{l}\text { Resource leveraging may also } \\
\text { diminish the company's } \\
\text { distinctive capabilities to } \\
\text { evaluate complex } \\
\text { entrepreneurial opportunities }\end{array}$ & $\begin{array}{l}\text { Resource leveraging may force a } \\
\text { company to enter alliances with } \\
\text { strategic partners to fully exploit } \\
\text { the opportunity. Strategic } \\
\text { partnering has many benefits } \\
\text { including:(1) lowering project } \\
\text { risks;(2) increasing intellectual } \\
\text { capital; and (3) providing access to } \\
\text { additional funding sources }\end{array}$ \\
\hline $\begin{array}{l}\text { Risk } \\
\text { management }\end{array}$ & $\begin{array}{l}\text { Dickson \& Giglierano [13] } \\
\text { "missing the boat vs } \\
\text { sinking the boat" risk }\end{array}$ & $\begin{array}{l}\text { Companies that are risk- } \\
\text { accepting will evaluate } \\
\text { opportunities using a risk- }\end{array}$ & $\begin{array}{l}\text { Risk management and acceptance } \\
\text { will result in a tendency to exploit } \\
\text { innovation }\end{array}$ \\
\hline
\end{tabular}




\begin{tabular}{|c|c|c|c|}
\hline & $\begin{array}{l}\text { assessment suggests that } \\
\text { opportunity discovery or } \\
\text { creation is in fact } \\
\text { attempting to manage risk }\end{array}$ & $\begin{array}{l}\text { adjusted framework and will } \\
\text { tend to accept speculative } \\
\text { opportunities that offer the } \\
\text { potential of building distinctive } \\
\text { capabilities }\end{array}$ & \\
\hline Innovation & $\begin{array}{l}\text { The strategic leveraging of } \\
\text { innovation should be the } \\
\text { impetus for the discovery } \\
\text { and creation of } \\
\text { opportunities }\end{array}$ & $\begin{array}{l}\text { Assessment should focus on } \\
\text { how the opportunity leverages } \\
\text { and builds the organization's } \\
\text { innovation capabilities }\end{array}$ & $\begin{array}{l}\text { Exploitation of opportunities should } \\
\text { be based on leveraging product, } \\
\text { process, administrative, or strategic } \\
\text { innovation }\end{array}$ \\
\hline $\begin{array}{l}\text { Opportunity- } \\
\text { driven }\end{array}$ & $\begin{array}{l}\text { Opportunity creation and } \\
\text { discovery must be driven } \\
\text { by the assessment of the } \\
\text { company's concept of } \\
\text { strategy }\end{array}$ & $\begin{array}{l}\text { Opportunity evaluation must be } \\
\text { based on the strategic relevance } \\
\text { of the opportunity }\end{array}$ & $\begin{array}{l}\text { Opportunity exploitation can be } \\
\text { based on either strategic on non- } \\
\text { strategic motives }\end{array}$ \\
\hline Proactive & $\begin{array}{l}\text { Proactive companies } \\
\text { attempt to create/discover } \\
\text { new opportunities that } \\
\text { enhance their distinctive } \\
\text { capabilities }\end{array}$ & $\begin{array}{l}\text { Proactive companies evaluate } \\
\text { entrepreneurial opportunities on } \\
\text { their ability to develop future } \\
\text { competitive advantage }\end{array}$ & $\begin{array}{l}\text { Proactive companies exploit } \\
\text { opportunities in such a way as to } \\
\text { enhance the opportunity to be a first } \\
\text { product/market/ technology space }\end{array}$ \\
\hline
\end{tabular}

Source: Miles \& Darroch [7].

\subsection{Measurement of small and medium-sized enterprise performance}

According to Radipere \& Dhliwayo [14], business performance is described as how good an organization is accomplishing its objectives. Company performance can also be explained as the capacity of a company to satisfy the intent of the organization and main stakeholders [15]. The high performance of small and medium-sized enterprises in their business operation is a guarantee for sustainability and helps to exploit global market opportunities [16].

Performance measures have great significance in effective management of an organization and in the enhancement of the processes since only measurable things are manageable. Hence, the enhancement of the organizational performance requires some measurements to determine the impact of the level of organizational effectiveness upon business performance [17]. As they mentioned in their study, Return on Assets (ROA), Return on Equity (ROE), Return on Sales (ROS), Profit Margin (PM), Earnings per Share (EPS), Tobin-Q, Market Value Added (MVA) and Market-to-Book Value (MTBV), while others are not widely used. Therefore, the performance of small and medium-sized enterprises in this study is measured based on sales, customer satisfaction, and the profit of the company compared to other competitors.

\section{Methodology}

This study focuses on legally registered small and medium-sized enterprises operating in Ethiopia, specifically in the city of Jimma. A purposive sampling technique was employed to gather data from 100 business owners that have been on the market for more than 7 years. The primary data was gathered by self-administered questionnaire adopted from Becherer et al. [18]. To make it easier for respondents to answer the questions and enable an efficient use of statistics for data interpretation, a 5-point Likert scale was used: Strongly Disagree $=1$, Disagree $=2$, Neutral $=3$, Agree $=4$, Strongly Agree $=5$.

Minitab and Statistical Software package for Social Science (SPSS) version 20 were employed to conduct multivariate statistical analysis (principal component analysis, factor analysis, cluster analysis, discriminant analysis), and other inferential statistics analysis, like multiple linear regression, to see the effects of the independent variables on the companies' performance (dependent variable). The general model for this specific study is as follows:

$$
\text { SMEP }=\alpha+\beta 1(P A) \text { it }+\beta 2(O F) \text { it }+\beta 3(R T O) \text { it }+\beta 4(I O) \text { it }+\beta 5(C I) \text { it }+\beta 6(R L) \text { it }+\beta 7(V C) \text { it }+ \text { eit }
$$

Where:

SMEP = small and medium-sized enterprise performance (dependent variable); $\alpha$ is a constant term; $\beta 1-\beta 7$ is coefficients for the respective explanatory variables; PA = Pro-activeness; OF = Opportunity Focused; RTO = Risk-Taking Orientation; IO = Innovation Oriented; $\mathrm{CI}=$ Customer Intensity; $\mathrm{RL}=$ Resource Leveraging; $\mathrm{VC}=$ Value Creation; $\varepsilon=$ error term. 


\section{Results and discussion}

In this section, the data gathered from the 100 respondents or company owners were analysed using the Minitab and SPSS statistical software packages. Inferential statistics analysis, like multiple linear regression, was applied to see the effect of the independent variables on the companies' performance (dependent variable), as well as multivariate statistical analysis (principal component analysis, factor analysis, cluster analysis, discriminant analysis).

\section{Regression Equation}

$\mathrm{SMEP}=1.256-0.0505 \mathrm{PA}-0.0361 \mathrm{OF}-0.1106 \mathrm{RTO}+0.8724 \mathrm{IO}+0.1239 \mathrm{CI}+0.0616 \mathrm{RL}$ $+0.0073 \mathrm{VC}$

Table 2. Model summary ${ }^{\mathrm{b}}$

\begin{tabular}{|c|c|c|c|c|c|}
\hline Model & $\mathrm{R}$ & $\mathrm{R}$ Square & Adjusted R Square & $\begin{array}{c}\text { Std. error of the } \\
\text { estimate }\end{array}$ & Durbin-Watson \\
\hline 1 & $.914^{\mathrm{a}}$ & .836 & .824 & .15895 & 1.534 \\
\hline
\end{tabular}

a. Predictors: (constant), VC, PA, IO, OF, RTO, CI, RL

b. Dependent variable: SMEP

Source: Authors - SPSS output.

As can be seen in Table 2 above, the regression model $\mathrm{R}$ square and adjusted $\mathrm{R}$ square statistics were $83.6 \%$ and $82.4 \%$ respectively. The result indicates that the changes in the independent variables explain $82.4 \%$ of the changes in the dependent variable. This means that the elements pro-activeness, opportunity focused, risk-taking orientation, innovation oriented, customer intensity, resource leveraging and value creation jointly explain $82.4 \%$ of the changes in the performance of small and medium-sized enterprises. The remaining $17.6 \%$ of the changes in their performance is therefore explained by other factors which were not included in this study. The result also indicates that all the variables included in this study are a good descriptive variable of the performance of small and medium-sized enterprises.

Table 3. ANOVA ${ }^{\mathrm{a}}$

\begin{tabular}{|ll|c|c|c|c|c|}
\hline Model & & Sum of Squares & df & Mean Square & F & Sig. \\
\hline \multirow{3}{*}{1} & Regression & 11.866 & 7 & 1.695 & 67.089 & $.000^{\mathrm{b}}$ \\
& Residual & 2.324 & 92 & .025 & & \\
& Total & 14.190 & 99 & & & \\
\hline
\end{tabular}

a. Dependent variable: SMEP

b. Predictors: (constant), VC, PA, IO, OF, RTO, CI, RL

Source: Authors - SPSS output.

From the statistical point of view, the ANOVA table shows the overall significance/acceptability of the model under use [19]. As shown in Table 3, the p-value is $<0.05$, i.e. 0.000 , which indicates that the variant explained by the model is not due to chance. This is also supported by the F-ratio $=67.089$, which confirms it is very unlikely to happen by chance. 
Table 4. Coefficients

\begin{tabular}{lrrrrr} 
Term & Coef & SE Coef & T-Value & P-Value & VIF \\
\hline Constant & 1.256 & 0.403 & 3.12 & 0.002 & \\
PA & -0.0505 & 0.0354 & -1.42 & 0.158 & 1.03 \\
OF & -0.0361 & 0.0746 & -0.48 & 0.630 & 1.05 \\
RTO & -0.1106 & 0.0333 & -3.32 & 0.001 & 1.10 \\
IO & 0.8724 & 0.0478 & 18.26 & 0.000 & 1.17 \\
CI & 0.1239 & 0.0566 & 2.19 & 0.031 & 1.14 \\
RL & 0.0616 & 0.0409 & 1.51 & 0.135 & 1.19 \\
VC & 0.0073 & 0.0468 & 0.16 & 0.876 & 1.09
\end{tabular}

Source: Authors - Minitab output.

As can be seen in Table 4 above, innovation oriented (IO) has a positive relationship with the dependent variable and is statistically significant at the $1 \%$ significance level, i.e. $(\beta=0.872 ; p$-value $=0.000)$. This indicates that as the innovation oriented variable changes, the performance of small and medium-sized enterprises changes in the same direction by 0.872 . Risk-taking orientation (RTO) has a negative relationship with the dependent variable and is statistically significant at the $5 \%$ significance level, i.e. $(\beta=-0.111$; -value $=0.001)$. This indicates that as the risk-taking orientation variable changes, the performance of small and medium-sized enterprises changes in the opposite direction by 0.111 . Customer intensity (CI) has a positive relationship with the dependent variable and is statistically significant at the $5 \%$ significance level, i.e. $(\beta=0.124 ; p$-value $=0.031)$. This indicates that as the customer intensity variable changes, the performance of small and medium-sized enterprises changes in the same direction by 0.124 .

Table 5. KMO and Bartlett's Test

\begin{tabular}{|c|c|c|}
\hline \multicolumn{2}{|l|}{ Kaiser-Meyer-Olkin measure of sampling adequacy. } & .515 \\
\hline & Approx. Chi-square & 205.976 \\
\hline Bartlett's test of sphericity & df & 28 \\
\hline & Sig. & .000 \\
\hline
\end{tabular}

Source: Authors - SPSS output.

KMO measure: the overall measure of sampling adequacy (MSA) for the set of variables included in the analysis was 0.515 , which exceeds the minimum requirement of 0.50 for overall MSA. It is therefore possible to conclude that the variables are correlated. The data also satisfy the criteria for appropriateness for factor analysis as the significance of Bartlett's test of sphericity is 0.000 , which is lower than 0.05 .

Table 6. Total variance explained

\begin{tabular}{|c|c|c|c|c|c|c|c|c|c|}
\hline \multirow[t]{2}{*}{$\begin{array}{l}\text { Compo } \\
\text { nent }\end{array}$} & \multicolumn{3}{|c|}{ Initial Eigenvalues } & \multicolumn{3}{|c|}{$\begin{array}{c}\text { Extraction Sums of Squared } \\
\text { Loadings }\end{array}$} & \multicolumn{3}{|c|}{ Rotation Sums of Squared Loadings } \\
\hline & Total & $\begin{array}{c}\% \text { of } \\
\text { Variance }\end{array}$ & Cumulative $\%$ & Total & $\begin{array}{c}\% \text { of } \\
\text { Variance }\end{array}$ & Cumulative $\%$ & Total & $\begin{array}{c}\% \text { of } \\
\text { Variance }\end{array}$ & $\begin{array}{c}\text { Cumulative } \\
\%\end{array}$ \\
\hline 1 & 2.282 & 28.523 & 28.523 & 2.282 & 28.523 & 28.523 & 2.237 & 27.968 & 27.968 \\
\hline 2 & 1.230 & 15.376 & 43.899 & 1.230 & 15.376 & 43.899 & 1.274 & 15.926 & 43.894 \\
\hline 3 & 1.155 & 14.437 & 58.336 & 1.155 & 14.437 & 58.336 & 1.155 & 14.442 & 58.336 \\
\hline 4 & .994 & 12.423 & 70.759 & & & & & & \\
\hline 5 & .876 & 10.953 & 81.712 & & & & & & \\
\hline 6 & .816 & 10.200 & 91.912 & & & & & & \\
\hline 7 & .557 & 6.961 & 98.873 & & & & & & \\
\hline 8 & .090 & 1.127 & 100.000 & & & & & & \\
\hline
\end{tabular}

Extraction method: Principal Component Analysis

Source: Authors - SPSS output. 
One of the most used techniques for dimension reduction or how many components (factors) to extract is known as Kaiser's criterion, or the eigenvalue rule. Using this rule, only factors with an eigenvalue of 1.0 or more are retained for further investigation. Accordingly, from Table 6 above, factors 1, 2 and 3 have an eigenvalue of 2.282, 1.230 and 1.155, respectively. Therefore, the three artificial components, i.e. Pro-activeness (PA), Opportunity Focused (OF) and Risk-Taking Orientation (RTO), explain 58.3\% of the total variance. So, 58.3\% of the information should be kept after the dimension reduction of the factors.

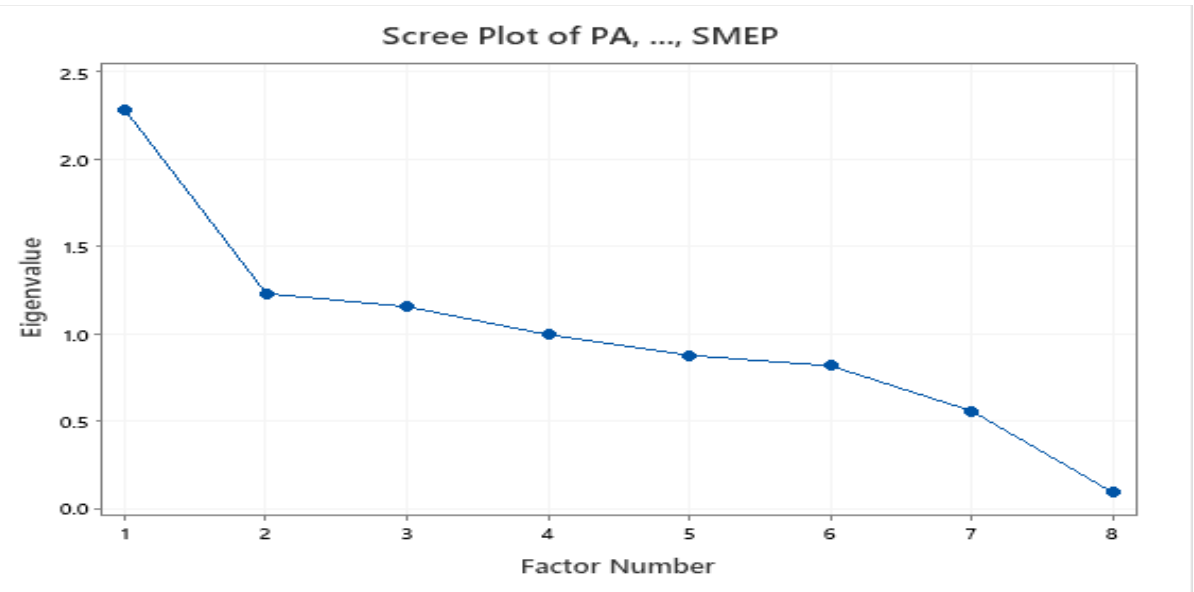

Figure 1. Scree plot of PA... SMEP

Source: Authors - Minitab output.

The scree plot in Figure 1 above graphically shows that factors 1, 2 and 3 have an eigenvalue greater than 1. This indicates that more than $50 \%$ of the total variance is explained by the three factors.

Table 7. Unrotated factor loadings and communalities

\begin{tabular}{lrrrrrrrrr} 
Variable & Factor1 & Factor2 & Factor3 & Factor4 & Factor5 & Factor6 & Factor7 & Factor8 & Communality \\
\hline PA & 0.003 & 0.549 & 0.012 & 0.718 & 0.133 & 0.383 & -0.138 & -0.016 & 1.000 \\
OF & -0.037 & 0.518 & 0.439 & -0.553 & 0.137 & 0.413 & 0.206 & -0.003 & 1.000 \\
RTO & -0.379 & -0.239 & -0.529 & -0.261 & 0.528 & 0.322 & -0.260 & -0.035 & 1.000 \\
IO & 0.887 & -0.129 & -0.079 & 0.056 & 0.354 & 0.067 & 0.131 & 0.202 & 1.000 \\
CI & 0.368 & 0.658 & -0.197 & -0.272 & 0.024 & -0.409 & -0.388 & 0.019 & 1.000 \\
RL & 0.563 & -0.277 & 0.119 & -0.142 & -0.484 & 0.435 & -0.385 & 0.008 & 1.000 \\
VC & -0.132 & -0.265 & 0.789 & 0.081 & 0.391 & -0.181 & -0.312 & 0.001 & 1.000 \\
SMEP & 0.938 & -0.084 & -0.005 & 0.020 & 0.220 & -0.044 & 0.119 & -0.218 & 1.000 \\
& & & & & & & & & 8.0000 \\
Variance & 2.2819 & 1.2301 & 1.1550 & 0.9939 & 0.8762 & 0.8160 & 0.5569 & 0.0902 & 1.000 \\
\% Var & 0.285 & 0.154 & 0.144 & 0.124 & 0.110 & 0.102 & 0.070 & 0.011 & \\
\end{tabular}

Source: Authors - Minitab output.

Table 7 above shows matrix A: loadings and communalities for unrotated factors. Three factors are independent and significant as can be seen in the factors' loadings (Factor 1, Factor 2 and Factor 3).

Table 8. Rotated factor loadings and communalities

\section{Varimax Rotation}

\begin{tabular}{lrrrrrrrrr} 
Variable & Factor1 & Factor2 & Factor3 & Factor4 & Factor5 & Factor6 & Factor7 & Factor8 & Communality \\
\hline PA & 0.001 & 0.050 & -0.997 & 0.028 & 0.028 & -0.019 & -0.049 & -0.002 & 1.000 \\
OF & 0.041 & 0.020 & -0.019 & 0.076 & -0.045 & -0.995 & 0.005 & -0.000 & 1.000 \\
RTO & 0.098 & -0.986 & 0.052 & -0.066 & 0.055 & 0.021 & -0.087 & -0.006 & 1.000 \\
IO & -0.970 & 0.003 & -0.027 & 0.053 & 0.021 & 0.028 & 0.123 & -0.198 & 1.000 \\
CI & -0.130 & 0.067 & -0.029 & 0.980 & 0.103 & -0.080 & -0.018 & 0.004 & 1.000 \\
RL & -0.216 & 0.091 & 0.053 & -0.020 & 0.037 & -0.006 & 0.970 & 0.003 & 1.000 \\
VC & 0.024 & 0.054 & 0.027 & -0.099 & -0.991 & -0.046 & -0.035 & 0.000 & 1.000 \\
SMEP & -0.937 & 0.149 & 0.031 & 0.132 & 0.014 & 0.029 & 0.165 & 0.232 & 1.000 \\
& & & & & & & 0.093 & 0.0928 & 0.012
\end{tabular}

Source: Authors - Minitab output. 
As is evident from the rotated factor loadings and communalities (Varimax Rotation) in Table 7 above, the communalities are not changed, but there are six significant factors with variances greater than 1 . The factor pattern structure has changed after rotation. Factor F1 has remained as is, a variable group, however, factor F2 has become a unique factor for the risk taking orientation (RTO) variable, factor F3 has become a unique factor for the pro-activeness (PA) variable, factor F4 has become a unique factor for the customer intensity (CI) variable, factor $\mathrm{F} 5$ has become a unique factor for the value creation (VC) variable, and factor $\mathrm{F} 6$ has become a unique factor for the opportunity focused (OP) variable. We can therefore conclude that the pro-activeness, risk taking orientation, customer intensity, value creation and opportunity focused variables are not correlated because the factors are supposed to be independent of one another.

\section{Conclusions}

The aim of this study was to determine the effect of entrepreneurial marketing on the performance of small and medium-sized enterprises in Ethiopia, specifically in the city of Jimma. Due to several constraints, small and medium-sized enterprises face marketing challenges [20] that force them to find alternative marketing strategies [21], which requires specific impact evaluation of variables [22]. According to the outcomes of the study presented in this contribution, certain elements of entrepreneurial marketing affect the performance of small and mediumsized enterprises, which is similar to the findings of Sherman et al. [23]. Innovation orientation and customer intensity have a positive relationship with the performance of small and medium-sized enterprises and are statistically significant, while risk-taking orientation has a negative relationship and is statistically significant. In general, non-traditional marketing strategies influence the performance of small and medium-sized enterprises.

\section{Reference}

1. S. Chitrakar, Market and Entrepreneurial Orientation of Nepalese Small and Medium Enterprises (SMEs). Synopsis of Ph. D. Thesis Submitted to: Office of Dean Faculty of Management. (2019)

2. D. Stokes, Putting Entrepreneurship into Marketing: The Processes of Entrepreneurial Marketing. Journal of Research in Marketing and Entrepreneurship. 2(1), 1-16 (2000)

3. R. C. Becherer, P. Haynes, L. Fletcher, Paths to Profitability in Owner-Operated Firms: The Role of Entrepreneurial Marketing. Journal of Business and Entrepreneurship. 18(1), 17 (2006)

4. M. Fink, M. Koller, J. Gartner, A. Floh, R. Harms, Effective entrepreneurial marketing on Facebook A longitudinal study. Journal of Business Research. 113, 149-157 (2018)

5. E. Hadiyati, Kajian Pendekatan Pemasaran Kewirausahaan dan Kinerja Penjualan Usaha Kecil [Study of Entrepreneurship Marketing Approach and Small Business Sales Performance]. Jurnal Manajemen Dan Kewirausahaan. 11(2), 183-192 (2009)

6. M. H. Morris, M. Schindehutte, R. W. LaForge, Entrepreneurial Marketing: A Construct for Integrating Emerging Entrepreneurship and Marketing Perspectives. Journal of Marketing Theory and Practice. 10(4), 1-19 (2002)

7. M. P. Miles, J. Darroch, Large firms, entrepreneurial marketing processes, and the cycle of competitive advantage. European Journal of Marketing. 40(5-6), 485-501 (2006)

8. R. Schulte, F. Eggers, Entrepreneurial marketing and the role of information - Evidence from young service ventures. International Journal of Entrepreneurship and Innovation Management. 11(1), 56-74 (2010)

9. E. J. Nijssen, Entrepreneurial Marketing: an effectual approach. $2^{\text {nd }}$ ed. London and New York: Routledge Taylor \& Francis Group (2014)

10. S. C. Morrish, M. P. Miles, J. H. Deacon, Entrepreneurial marketing: Acknowledging the entrepreneur and customer-centric interrelationship. Journal of Strategic Marketing. 18(4), 303-316 (2010)

11. M. Schindehutte, M. H. Morris, A. Kocak, Understanding Market-Driving Behavior: The Role of Entrepreneurship. Journal of Small Business Management. 46(1), 4-26 (2008)

12. S. Kraus, R. Harms, M. Fink, Entrepreneurial marketing: Moving beyond marketing in new ventures. International Journal of Entrepreneurship and Innovation Management. 11(1), 19-34 (2010)

13. P. R. Dickson, J. J. Giglierano, Missing the Boat and Sinking the Boat: A Conceptual Model of Entrepreneurial Risk. Journal of Marketing. 50(3), 58-71 (1986) 
14. S. Radipere, S. Dhliwayo, The role of gender and education on small business performance in the South African small enterprise sector. Mediterranean Journal of Social Sciences. 5(9), 104-110 (2014)

15. T. M. Smith, J. S. Reece, The relationship of strategy, fit, productivity, and business performance in a services setting. Journal of Operations Management. 17(2), 145-161 (1999)

16. I. M. Aminu, M. N. M. Shariff, Influence of strategic orientation on SMEs access to finance in Nigeria. Asian Social Science. 11(4), 298-309 (2015)

17. E. M. Al-Matari, A. K. Al-Swidi, F. H. B. Fadziah, The Measurements of Firm Performance's Dimensions. Asian Journal of Finance \& Accounting. 6(1), 24-49 (2014)

18. R. C. Becherer, M. M. Helms, J. P. McDonald, The effect of entrepreneurial marketing on outcome goals in SMEs. New England Journal of Entrepreneurship. 15(1), 7-18 (2012)

19. C. Acton, R. L. Miller, J. Maltby, D. A. Fullerton, J. Campling, Analysis of Variance (ANOVA). SPSS for Social Scientists. 6, 183-198 (2009)

20. S. C. Morrish, Entrepreneurial marketing: A strategy for the twenty-first century? Journal of Research in Marketing and Entrepreneurship. 13(2), 110-119 (2011)

21. A. Maritz, H. Frederick, M. Valos, A discursive approach to entrepreneurial marketing: Integrating academic and practice theory. Small Enterprise Research. 17(1), 74-86 (2010)

22. G. S. Mort, J. Weerawardena, P. Liesch, Advancing entrepreneurial marketing: Evidence from born global firms. European Journal of Marketing. 46(3-4), 542-561 (2012)

23. H. Sherman, J. Shuart, L. Weinstein, New England Journal of Entrepreneurship. New England Journal of Entrepreneurship. 10(2), 5 (2007) 